\title{
Serum Resistin and Plasma Visfatin: Relation to Insulin Resistance and Hyperandrogenism in Women with Polycystic Ovary Syndrome
}

\author{
Hanan Hosni Ahmed * and Nevein Kamal Ghamry ** \\ Departments of Medical Biochemistry* and Obstetrics and \\ Gynecology, **Faculty of Medicine, Cairo University
}

\begin{abstract}
Polycystic ovary syndrome (PCOS) is a heterogeneous syndrome characterized by hyperandrogenism and insulin resistance. The mechanism that is responsible for insulin resistance is unclear and several hypotheses have been suggested. Resistin, and visfatin, a new protein with potential insulin-mimetic action are adipokines which are suggested to play a role in the pathogenesis of insulin resistance. The aim of the study is to assess the relationship between both serum resistin and plasma visfatin and insulin resistance and hyperandrogenism in PCOS patients. The present study included 60 women with polycystic ovary syndrome (PCOS) (group II: 30 with BMI < $25 \mathrm{~kg} / \mathrm{m}^{2}$ and group IV: 30 with BMI $>25 \mathrm{~kg} / \mathrm{m}^{2}$ ) and 20 healthy women (group I: 10 with $B M I<25 \mathrm{~kg} / \mathrm{m}^{2}$ and group III: 10 with BMI $>25 \mathrm{~kg} / \mathrm{m}^{2}$ ) served as controls. Fasting blood samples were withdrawn between the $3^{\text {rd }}$ and the $6^{\text {th }}$ day of the menstrual cycle of the ovulating women and between the $3^{\text {rd }}$ and the $6^{\text {th }}$ day of a spontaneous bleeding of the anovulatory women. Serum LH, FSH free testosterone, resistin, plasma glucose, insulin and visfatin were estimated in all patients and controls. Insulin resistance was assessed using the homeostatic assessment model (HOMA). Resistin and visfatin levels were significantly higher in women with PCOS $(13.26 \pm 7.58 \mathrm{ng} / \mathrm{ml}$ and $35.82 \pm 8.94 \mathrm{ng} / \mathrm{ml})$ than normal controls $(7.95 \pm 2.17 \mathrm{ng} / \mathrm{ml}$ and $11.88 \pm 1.84 \mathrm{ng} / \mathrm{ml})(p=0.003, p<0.0001)$, respectively. Serum resistin levels in groups III and IV were significantly higher compared to groups I and II $(p<0.001$, $p<0.001$ ) being higher in group $I V$, whereas no significant difference existed between groups I and II. Resistin correlated positively with BMI, fasting plasma glucose, fasting plasma insulin and HOMA index in women with BMI $>25 \mathrm{~kg} / \mathrm{m}^{2}$ (groups III and IV).In other words, resistin was found to correlate significantly with all obesityassociated parameters. Plasma visfatin levels were significantly higher in groups II and IV being higher in group IV when compared to the control groups I and III, whereas no significant difference existed between control groups I and III. Visfatin also positively correlated with, fasting plasma insulin $(r=0.882, p<0.01$ and $r=$ $0.952, p<0.01)$ and HOMA $(r=0.908, p<0.01$ and $r=0.942, p<0.01)$ in women with PCOS (groups II and IV), respectively. In women with PCOS (groups II and IV), both resistin and visfatin positively correlated with free testosterone $(r=0.6, p=$ 0.003 and $r=0.973, p<0.01)$ and $(r=0.969, p<0.01$ and $r=0.922, p<0.01)$, respectively. In women with PCOS (groups II and IV), resistin correlated positively with visfatin ( $r=0.784, p<0.01, r=0.954, p<0.01$ ), respectively. From the current
\end{abstract}


data, it could be suggested that resistin levels correlate with insulin resistance as a consequence of obesity itself, rather than a, causative factor. Also the possibility that resistin may play a role in augmenting androgen biosynthesis in women with PCOS could arise. We presume that, in PCOS the increase in plasma visfatin is a secondary event in order to prevent further development of insulin resistance. Finally, the insulin-like visfatin action might stimulate ovarian androgen synthesis and secretion and thus contribute to the pathogenesis of PCOS.

Key Words: Polycystic ovary syndrome (PCOS), resistin, visfatin, insulin resistance, hyperandrogenism.

\section{INTRODUCTION}

Polycystic ovary syndrome (PCOS), is a very common endocrine disorder affecting up to $10 \%$ of women of reproductive age. It is expressed as chronic anovulation and hyperandrogenism ${ }^{(1,2)}$, and its clinical manifestations often start at puberty ${ }^{(3)}$. Insulin resistance with compensatory hyperinsulinismia is a prominent feature of PCOS. Both lean and obese women with PCOS show reduced insulin sensitivity and hyperinsulinemia to some extent, but insulin resistance is enhanced by the interaction between obesity and the syndrome ${ }^{(4)}$.

Hyperinsulinismia is thought to result in increased androgen biosynthesis ${ }^{(5)}$ and decreased levels of sex- hormone-binding globulin $(\mathrm{SHBG})^{(6)}$, thus playing a major role in the pathogenesis of hyperandrogenism .In addition to reproductive morbidity, insulin resistance and the resultant hyperinsulinism put patients at risk for long -term metabolic disorders, such as impaired glucose tolerance (up to $35 \%$ ) and type 2 diabetes (up to $10 \%)^{(7)}$, as well as cardiovascular disease $^{(8)}$.

The mechanism that is responsible for insulin resistance is unclear and several hypotheses have been suggested ${ }^{(\mathbf{9})}$. Because obesity is linked to insulin resistance and many women with PCOS are obese, it is possible that, at least in a subgroup of patients, insulin resistance is worsened by excessive adipose mass ${ }^{(\mathbf{1 0})}$

The adipose tissue is now considered an active organ, secreting substances, which may play a role in the pathogenesis of insulin resistance $^{(11)}$. In recent years, numerous studies pointed out that socalled true adipokines (adiponectin, leptin), secreted only by fat cells, as well as other adipocytokines (tumor necrosis factor- $\alpha$, resistin, interleukin 6 , interleukin 18), which can be secreted also by stromal cells in adipose tissue, play a significant role in the regulation of insulin sensitivity ${ }^{(12,13,14,15,16,17)}$.

One of the recently identified molecules of this kind is resistin, a 114-amino-acid peptide ${ }^{(15,18,19)}$. Resistin is an adipokine belonging to a recently described family of small cysteine-rich secreted proteins ${ }^{(\mathbf{2 0})}$ that is induced during adipocyte differentiation $^{(19)}$ and down-regulated by insulin-sensitizing agents ${ }^{(15)}$. In mice, resistin has been linked to insulin resistance. Administration of recombinant resistin impaired insulin 
action and glucose tolerance, whereas administration of antiresistin antibodies improved insulin action ${ }^{(\mathbf{1 5})}$.

In humans, low levels of resistin mRNA and protein expression were initially reported in isolated subcutaneous and omental adipocytes $^{(21,22,23)}$. A high level of resistin gene expression was observed in human preadipocytes that decreased during adipogenic differentiation ${ }^{(24)}$. Resistin mRNA was also found in human monocytes ${ }^{(21)}$. Differentiation of monocytes into macrophages in vitro increases resistin mRNA $^{(25)}$. Together, these observations demonstrate that there are multiple cellular sources of resistin in humans and that circulating resistin represents resistin from adipocytes as well as from the stromovascular compartment.

The relationship between resistin and insulin resistance and adiposity in humans is controversial. Whereas some studies observed a positive association between resistin and insulin resistance ${ }^{(26,27,28)}$, others failed to demonstrate a relationship ${ }^{(29,30)}$.

In 2005, visfatin, a new protein was discovered ${ }^{(31)}$. Visfatin, also known as pre-B cell colony-enhancing factor, is a cytokine that is highly expressed in visceral fat and was originally isolated as a secreted factor that synergizes with IL-7 and stem cell factors to promote the growth of $\mathrm{B}$ cell precursors ${ }^{(32)}$. It reportedly has insulin-mimetic actions, mediated by activation of the insulin receptor in a manner distinct from that of insulin $^{(31)}$. Also, plasma levels increased with obesity and correlated positively with visceral adiposity ${ }^{(31)}$. Berndt et al. ${ }^{(33)}$ did not find a relation between visfatin and insulin sensitivity. Others revealed conflicting data regarding the role of visfatin in regulation of insulin sensitivity in humans ${ }^{(31,34)}$

Insulin resistance and increased visceral adipose tissue and hyperandrogenism are the hallmarks of PCOS. The aim of the present work was to assess the relationship between both serum resistin and plasma visfatin and insulin sensitivity and hyperandrogenism in PCOS patients.

\section{SUBJECTS \& METHODS}

Sixty women with PCOS were enrolled in the present study along with twenty healthy women with regular menstrual cycles to serve as control subjects. Women with PCOS were selected from the Gynecology Outpaient Clinic at Kasr El Aini Hospital, Cairo University. Women with PCOS had a mean age of $27.8 \pm 4.31$ years and mean body mass index (BMI) of $27.17 \pm 5.91 \mathrm{Kg} / \mathrm{m}^{2}$.

The diagnosis of PCOS was based on the revised 2003 consensus on PCOS diagnostic criteria ${ }^{(35)}$. These criteria included findings of hyperandrogenism of ovarian origin (hirsutism with or without acne), chronic anovulation (both oligmenorrhea and amenorrhea), a typical ovarian appearance on transvaginal ultra sound examination and an increased ratio of $\mathrm{LH}$ to FSH .A precise medical and obstetric history including BMI was obtained. The BMI was calculated as body weight in kilograms divided by height in meters squared $\left(\mathrm{kg} / \mathrm{m}^{2}\right)^{(36)}$.

Exclusion criteria for the study included known cardiovascular 
disease, thyroid disease, neoplasms, current smoking, diabetes mellitus, hypertension (blood pressure $>140 / 90$ $\mathrm{mm} \mathrm{Hg}$ ) and renal impairment. Furthermore, other common causes of hyperandrogenism (prolactinoma, congenital adrenal hyperplasia, Cushing syndrome, and virilizing ovarian or adrenal tumors) were excluded. None of these women, PCOS and controls, were on any medications for at least 6 months before the study, including oral contraceptives; glucocorticoids; ovulation induction agents; antidiabetic and antiobesity drugs; or estrogenic, antiandrogenic, or antihypertensive medication.

Twenty normal ovulatory females with a mean age of $27.9 \pm$ 4.44 years and mean body mass index of $26.75 \pm 5.29 \mathrm{Kg} / \mathrm{m}^{2}$ served as a control. They were selected from the Kasr El Aini family planning and gynecological outpatient clinic.

The eighty women were divided into 4 groups based on BMI and the diagnosis of PCOS as follows.

Group I: comprised 10 ovulatory females without hyperandrogenemia (controls and BMI $<25 \mathrm{~kg} / \mathrm{m}^{2}$ ).

Group II: comprised 30 females with PCOS and BMI $<25 \mathrm{~kg} / \mathrm{m}^{2}$.

Group III: comprised 10 ovulatory females without hyperandrogenemia (controls and BMI $>25 \mathrm{~kg} / \mathrm{m}^{2}$ ).

Group IV: comprised 30 females with PCOS and BMI $>25 \mathrm{~kg} / \mathrm{m}^{2}$.

Sampling:

After an over night fast, blood samples were withdrawn between the $3^{\text {rd }}$ and the $6^{\text {th }}$ day of the menstrual cycle of the ovulating women and between the $3^{\text {rd }}$ and the $6^{\text {th }}$ day of a spontaneous bleeding of the anovulatory women. An informed written consent was obtained from all 80 women. Serum/plasma were immediately aliquoted on ice and stored at -80 C. Fasting plasma glucose was measured immediately with the glucose oxidase/peroxidase $\operatorname{method}^{(37)}$. Insulin was measured using the radioimmunoassay kit supplied by Linco Research, Inc. ${ }^{(38)}$ (St Charles, MO, USA). LH $^{(39)}$ and $\mathrm{FSH}^{(40)}$ were measured with the available commercial kits (ELISA) provided by DRG Diagnostics GmbH, Germany $^{(\mathbf{4 1})}$ Free testosterone was measured with an enzymeimmunoassay (EIA) supplied by Diagnostic Systems Laboratories (DSL-10-49100) , Inc. Webster, Texas USA. The LH/FSH ratio was calculated and the insulin sensitivity was estimated using the homeostatic model assessement (HOMA) index. HOMA-R $=[$ fasting insulin $(\mathrm{uU} / \mathrm{ml}) \times$ fasting serum glucose $(\mathrm{mg} / \mathrm{dl})] / 405^{(42)}$. Serum resistin levels were measured with a commercial ELISA kit supplied by Biovender $\mathrm{GmbH}$, Heidelberg, Germany $^{(38)}$. Plasma visfatin levels were measured with a commercial ELISA kit supplied by BioSource International, Inc. Camarillo, California USA ${ }^{(31)}$.

\section{Statistical Analysis:}

The statistical analysis of data was done by using Excel program and statistical package of social science (SPSS) program version 10. Values were expressed as mean $\pm \mathrm{SD}$. For comparison of means between groups student t- test, ANOVA and post-hoc tests were used. The relationships between resistin and visfatin and other variables were assessed using the 
Pearson correlation. The level of significance was $\mathrm{p}<0.05$.

\section{RESULTS}

The clinical and biochemical parameters of women with PCOS and healthy controls are summarized in table 1.There was no major difference between the two groups with respect to age, BMI and fasting plasma glucose. Compared to the controls, women with PCOS had significantly higher serum concentrations of $\mathrm{LH}$ $(\mathrm{p}<0.001), \mathrm{LH} / \mathrm{FSH}$ ratio $(\mathrm{p}<0.001)$ and free testosterone $(\mathrm{p}<0.001)$. Women with PCOS had significantly lower FSH levels compared to controls $(p<0.001)$.

The plasma insulin levels were significantly higher $(p<0.001)$ in PCOS compared to the control group. Women with PCOS had significantly higher HOMA values compared to matched controls consistent with the PCOS group being more insulin resistant than the control group.

Mean serum resistin levels was significantly higher in PCOS women $(13.26 \pm 7.58 \mathrm{ng} / \mathrm{ml})$ compared to normal controls $(7.95 \pm 2.17 \mathrm{ng} / \mathrm{ml})$ $(p=0.003)$. Also, mean plasma visfatin levels was significantly higher in PCOS women $(35.82 \pm 8.94 \mathrm{ng} / \mathrm{ml})$ compared to normal controls $(11.88 \pm 1.84 \mathrm{ng} / \mathrm{ml})(\mathrm{p}<0.0001)$.

Table 1: Clinical and biochemical parameters of women with PCOS and healthy controls.

\begin{tabular}{|l|l|l|l|}
\hline & $\begin{array}{l}\text { Control } \\
\text { N=20 }\end{array}$ & $\begin{array}{l}\text { PSOC } \\
\text { N=60 }\end{array}$ & P value \\
\hline Age $($ years $)$ & $27.9 \pm 4.44$ & $27.8 \pm 4.31$ & 0.929 \\
\hline BMI $\left(\mathrm{Kg} / \mathrm{m}^{2}\right)$ & $26.75 \pm 5.29$ & $27.17 \pm 5.91$ & 0.77 \\
\hline FSH $(\mathrm{mIU} / \mathrm{ml})$ & $6.49 \pm 1.2$ & $4.32 \pm 0.72$ & $<0.0001$ \\
\hline LH $(\mathrm{mIU} / \mathrm{ml})$ & $4.02 \pm 0.52$ & $14.05 \pm 4.83$ & $<0.0001$ \\
\hline LH/FSH ratio & $0.63 \pm 0.12$ & $3.32 \pm 1.21$ & $<0.0001$ \\
\hline Free testosterone $(\mathrm{pg} / \mathrm{ml})$ & $1.6 \pm 0.35$ & $5.51 \pm 2.18$ & $<0.0001$ \\
\hline Fasting plasma glucose $(\mathrm{mg} / \mathrm{dl})$ & $93.7 \pm 10.21$ & $94.58 \pm 9.31$ & 0.721 \\
\hline Fasting plasma Insulin $(\mu \mathrm{IU} / \mathrm{ml})$ & $7.98 \pm 1.82$ & $13.37 \pm 4.63$ & $<0.0001$ \\
\hline HOMA & $1.93 \pm 0.77$ & $3.19 \pm 1.37$ & $<0.0001$ \\
\hline Serum Resistin $(\mathrm{ng} / \mathrm{ml})$ & $7.95 \pm 2.17$ & $13.26 \pm 7.58$ & 0.003 \\
\hline Plasma Visfatin $(\mathrm{ng} / \mathrm{ml})$ & $11.88 \pm 1.84$ & $35.82 \pm 8.94$ & $<0.0001$ \\
\hline
\end{tabular}

Values are expressed as mean $\pm S D$.

$P<0.05$ was considered significant. 
Clinical and biochemical parameters of all subjects based on BMI stratification are summarized in table 2. Groups III and IV had significantly higher BMI compared to groups I and II $(p<0.001)$. Women with PCOS (groups II and IV) had significantly lower FSH levels $(\mathrm{p}<$ 0.001) compared to control groups (I and III) In contrast, LH levels were significantly higher in women with PCOS (groups II and IV) compared to control groups (I and III) $(\mathrm{p}<0.001)$. Also, women with PCOS with BMI > $25 \mathrm{Kg} / \mathrm{m}^{2}$ had higher $\mathrm{LH}$ levels than women with PCOS with $\mathrm{BMI}<25 \mathrm{Kg} /$ $\mathrm{m}^{2}$. The same results were detected as regards the LH/FSH ratio $(\mathrm{p}<0.001)$. Women with PCOS (group IV) had significantly higher free testosterone levels $(p<0.001)$ compared to PCOS (group II).

Blood glucose levels were significantly higher in women with $\mathrm{BMI}>25 \mathrm{Kg} / \mathrm{m}^{2}$ (group III versus I; $\mathrm{p}<$ 0.05 ; group IV versus I; $p<0.001$; IV versus II ; $\mathrm{p}<0.001$ ) whereas no significant difference was observed between women with $\mathrm{BMI}<25 \mathrm{Kg} / \mathrm{m}^{2}$ of groups I and II .Compared to normal controls (groups I and III), women with PCOS with BMI > $25 \mathrm{Kg} / \mathrm{m}^{2}$ had significantly higher plasma insulin levels $(\mathrm{p}<0.001$ and $\mathrm{p}<$ 0.001), respectively. Also, control group III had significantly higher plasma insulin level $(\mathrm{p}<0.001)$ compared to control group I. However, insulin resistance (assessed by HOMA) was significantly higher in women with PCOS with BMI > $25 \mathrm{Kg} / \mathrm{m}^{2}$ compared to groups I, II and III $(\mathrm{p}<0.001, \mathrm{p}<0.001$ and $\mathrm{p}<0.001)$, respectively.

Serum resistin levels in groups III and IV were significantly higher compared to groups I and II $(\mathrm{p}<$ $0.001, \mathrm{p}<0.001$ ) being higher in women with PCOS with BMI > $25 \mathrm{Kg} / \mathrm{m}^{2}$. Whereas no significant difference existed between women with PCOS with BMI $<25 \mathrm{Kg} / \mathrm{m}^{2}$ and control women with $\mathrm{BMI}<25 \mathrm{Kg} / \mathrm{m}^{2}$ (Fig.1).

Plasma visfatin levels were significantly higher in women with PCOS (groups II and IV) being higher in in women with PCOS with BMI > $25 \mathrm{Kg} / \mathrm{m}^{2}$ when compared to the control groups (I and III). Whereas no significant difference existed between control groups (I and III) (Fig.2). 
Table 2: Clinical and biochemical parameters of all subjects based on BMI stratification

\begin{tabular}{|c|c|c|c|c|c|}
\hline & \multicolumn{2}{|c|}{$\mathrm{BMI}<25 \mathrm{Kg} / \mathrm{m}^{2}$} & \multicolumn{2}{|c|}{ BMI $>25 \mathrm{Kg} / \mathrm{m}^{2}$} & \multirow[b]{2}{*}{$\begin{array}{c}\text { ANOVA } \\
\text { p value }\end{array}$} \\
\hline & $\begin{array}{c}\text { Group I } \\
\text { Control } \\
\mathbf{N}=10\end{array}$ & $\begin{array}{c}\text { Group II } \\
\text { PCOS } \\
\mathbf{N}=30\end{array}$ & $\begin{array}{c}\text { Group III } \\
\text { Control } \\
\mathbf{N}=10\end{array}$ & $\begin{array}{c}\text { Group IV } \\
\text { PCOS } \\
\mathbf{N}=30\end{array}$ & \\
\hline Age (years) & $\begin{array}{c}28.1 \pm 4.86 \\
\text { (a) }\end{array}$ & $\begin{array}{l}27.23 \pm 4.4 \\
\text { (a) }\end{array}$ & $\begin{array}{l}27.7 \pm 4.24 \\
\text { (a) }\end{array}$ & $\begin{array}{c}28.36 \pm 4.22 \\
\text { (a) }\end{array}$ & $>0.05$ \\
\hline BMI (Kg/ m²) & $\begin{array}{c}22.35 \pm 1.83 \\
\text { (a) }\end{array}$ & $\begin{array}{c}22.33 \pm 1.86 \\
\text { (a) }\end{array}$ & $\begin{array}{c}31.16 \pm 3.55 \\
\text { (b) }\end{array}$ & $\begin{array}{c}2.02 \pm 4.37 \\
\text { (b) }\end{array}$ & $<0.01$ \\
\hline FSH (mIU/ml) & $\begin{array}{c}7.22 \pm 1.18 \\
\text { (b) }\end{array}$ & $\begin{array}{l}4.36 \pm 0.69 \\
\text { (a) }\end{array}$ & $\begin{array}{l}5.77 \pm 0.68 \\
\text { (c) }\end{array}$ & $\begin{array}{c}4.27 \pm 0.75 \\
\text { (a) }\end{array}$ & $<0.01$ \\
\hline LH (mIU/ml) & $\begin{array}{c}4.06 \pm 0.56 \\
\text { (a) }\end{array}$ & $\begin{array}{c}10.95 \pm 1.79 \\
\text { (b) }\end{array}$ & $\begin{array}{c}3.98 \pm 0.5 \\
\text { (a) }\end{array}$ & $\begin{array}{l}17.16 \pm 4.94 \\
\text { (c) }\end{array}$ & $<0.01$ \\
\hline LH/FSH ratio & $\begin{array}{c}0.56 \pm 0.07 \\
\text { (a) }\end{array}$ & $\begin{array}{c}2.56 \pm 0.62 \\
\text { (b) }\end{array}$ & $\begin{array}{c}0.69 \pm 0.122 \\
\text { (a) }\end{array}$ & $\begin{array}{c}4.07 \pm 1.19 \\
\text { (c) }\end{array}$ & $<0.01$ \\
\hline Free testosterone $(\mathrm{pg} / \mathrm{ml})$ & $\begin{array}{c}1.4 \pm 0.29 \\
\text { (a) }\end{array}$ & $\begin{array}{c}3.79 \pm 0.8 \\
\text { (c) }\end{array}$ & $\begin{array}{c}1.42 \pm 0.28 \\
\text { (a) }\end{array}$ & $\begin{array}{c}7.23 \pm 1.71 \\
\text { (d) }\end{array}$ & $<0.01$ \\
\hline Fasting plasma glucose (mg/dl) & $\begin{array}{c}89.1 \pm 9.25 \\
\text { (a) }\end{array}$ & $\begin{array}{c}89 \pm 4.16 \\
\text { (a) }\end{array}$ & $\begin{array}{c}98.3 \pm 9.36 \\
\text { (b) }\end{array}$ & $\begin{array}{c}100.16 \pm 9.72 \\
\text { (c) }\end{array}$ & $<0.01$ \\
\hline Fasting plasma Insulin( $\mu \mathrm{IU} / \mathrm{ml})$ & $\begin{array}{c}6.48 \pm 0.68 \\
\text { (a) }\end{array}$ & $\begin{array}{c}9.14 \pm 1.26 \\
\text { (b) }\end{array}$ & $\begin{array}{c}9.48 \pm 1.24 \\
\text { (b) }\end{array}$ & $\begin{array}{c}17.61 \pm 2.22 \\
\text { (c) }\end{array}$ & $<0.01$ \\
\hline HOMA & $\begin{array}{c}1.41 \pm 0.24 \\
\text { (a) }\end{array}$ & $\begin{array}{c}1.99 \pm 0.28 \\
\text { (b) }\end{array}$ & $\begin{array}{c}2.45 \pm 0.77 \\
\text { (c) }\end{array}$ & $\begin{array}{c}4.38 \pm 0.91 \\
\text { (d) }\end{array}$ & $<0.01$ \\
\hline Serum Resistin (ng/ml) & $\begin{array}{c}6.18 \pm 0.94 \\
\text { (a) }\end{array}$ & $\begin{array}{c}6.37 \pm 0.81 \\
\text { (a) }\end{array}$ & $\begin{array}{c}9.72 \pm 1.46 \\
\text { (b) }\end{array}$ & $\begin{array}{l}20.14 \pm 4.26 \\
\text { (c) }\end{array}$ & $<0.01$ \\
\hline Plasma Visfatin (ng/ml) & $\begin{array}{c}11.65 \pm 1.73 \\
\text { (a) }\end{array}$ & $\begin{array}{c}27.87 \pm 4.14 \\
\text { (b) }\end{array}$ & $\begin{array}{c}12.11 \pm 2.02 \\
\text { (a) }\end{array}$ & $\begin{array}{c}43.78 \pm 3.85 \\
\text { (c) }\end{array}$ & $<0.01$ \\
\hline
\end{tabular}

Values are expressed as mean $\pm \mathrm{SD}$

$P<0.05$ was considered significant.

Same letters $(a, b, c, d)$ under each group indicate a non- significant difference between groups.

Different letters under each group indicate a significant difference between groups.

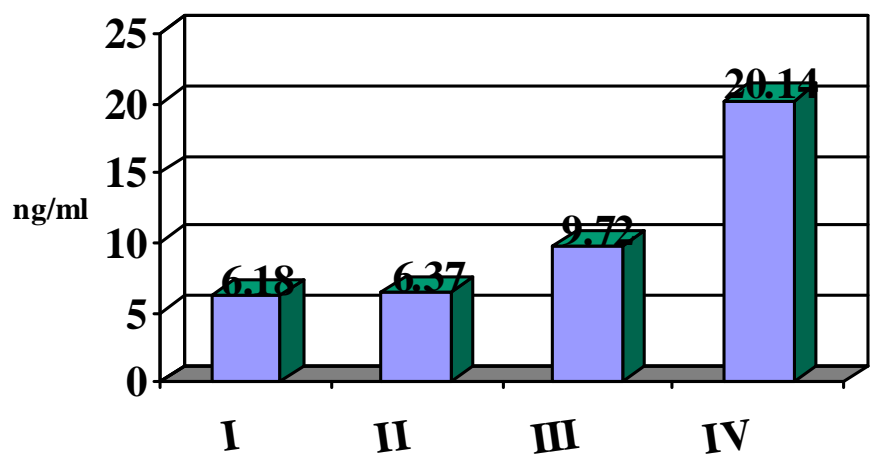

Fig (1): Serum resistin levels (ng/ml) in studied groups 


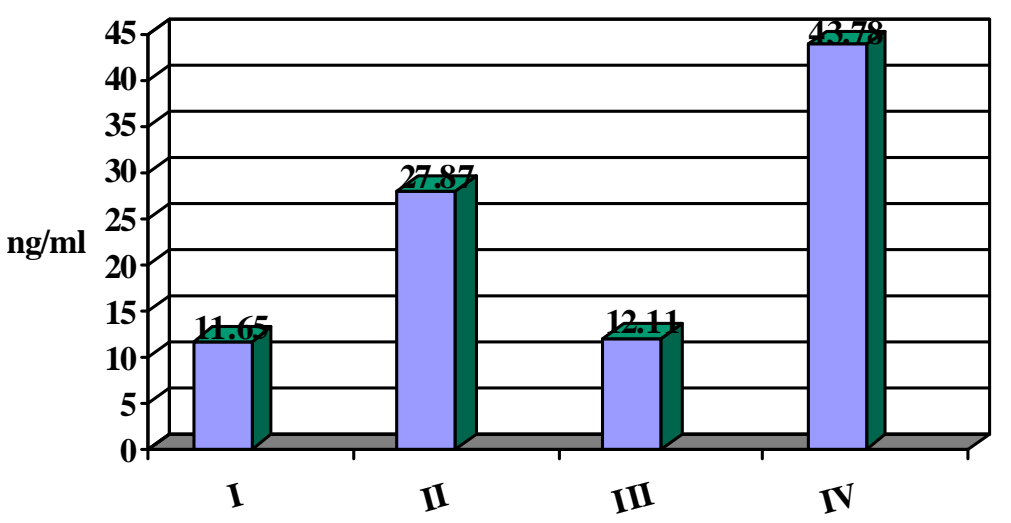

Fig (2): Plasma visfatin levels (ng/ml) in studied groups

Calculation of Pearson coefficient showed that in the whole study group, resistin correlated positively with BMI, LH, LH/FSH ratio, plasma insulin, fasting plasma glucose, free testosterone, HOMA and visfatin. Serum resistin levels were found to correlate negatively with FSH (table 3 ). In subgroup analysis, the positive correlation between serum resistin and BMI was present in women with PCOS and BMI $>25 \mathrm{Kg} / \mathrm{m}^{2}(\mathrm{r}=$ $0.963, \mathrm{p}<0.01)$ and in control group with $\mathrm{BMI}>25 \mathrm{Kg} / \mathrm{m}^{2}(\mathrm{r}=0.953, \mathrm{p}<$ 0.01 ) but not in women with PCOS with $\mathrm{BMI}<25 \mathrm{Kg} / \mathrm{m}^{2}(\mathrm{r}=0.213, \mathrm{p}$ $=0.258$ ) or the control group with $\mathrm{BMI}<25 \mathrm{Kg} / \mathrm{m}^{2}(\mathrm{r}=-0.512, \mathrm{p}=0.13)$. Resistin also positively correlated with fasting plasma glucose $(\mathrm{r}=0.818$, $\mathrm{p}<0.01$ and $\mathrm{r}=0.457, \mathrm{p}=0.043)$, fasting plasma insulin $(\mathrm{r}=.938, \mathrm{p}<$ 0.01 and $r=0.706, p=0.001)$ and HOMA $(\mathrm{r}=0.931, \mathrm{p}<0.01$ and $\mathrm{r}=$ $0.645, \mathrm{p}=0.002$ ) in women with PCOS and BMI $>25 \mathrm{Kg} / \mathrm{m}^{2}$ and in controls with BMI $>25 \mathrm{Kg} / \mathrm{m}^{2}$ respectively. Additionally, in women with PCOS (groups II and IV), resistin positively correlated with free testosterone $(\mathrm{r}=0.6, \mathrm{p}=0.003$ and $\mathrm{r}=$ $0.973, \quad p<0.01)$. There was no significant correlation between resistin and free testosterone concentrations in control subjects $(\mathrm{r}=$ $0.031, \mathrm{p}=0.932$ and $\mathrm{r}=0.063, \mathrm{p}=$ $0.085)$, respectively. In women with PCOS (groups II and IV), resistin correlated positively with visfatin $(\mathrm{r}=$ $.784, \mathrm{p}<0.01, \mathrm{r}=0.954, \mathrm{p}<0.01)$, respectively. 
Table 3: Correlations between resistin and anthropometric, biochemical and hormonal parameters in the whole study group

\begin{tabular}{|l|c|c|}
\hline Parameters & $\mathrm{r}$ & $\mathrm{p}$ \\
\hline Age & 0.089 & 0.433 \\
BMI & 0.866 & $<0.01$ \\
FSH & -0.469 & 0.037 \\
LH & 0.638 & $<0.01$ \\
LH/FSH & 0.582 & $<0.01$ \\
Free testosterone & 0.877 & $<0.01$ \\
Fasting plasma glucose & 0.676 & $<0.01$ \\
Fasting plasma insulin & 0.951 & $<0.01$ \\
HOMA & 0.951 & $<0.01$ \\
Visfatin & 0.784 & $<0.01$ \\
\hline
\end{tabular}

$P<0.05$ was considered significant.

Calculation of Pearson coefficient showed that in the whole study group, visfatin correlated positively with BMI, LH, LH/FSH ratio, plasma insulin, fasting plasma glucose, free testosterone, HOMA and resistin (table 4). In subgroup analysis, the correlation between plasma visfatin and BMI was present in women with PCOS with BMI $>25 \mathrm{Kg} / \mathrm{m}^{2}$ and $\mathrm{BMI}<25 \mathrm{Kg} / \mathrm{m}^{2}(\mathrm{r}=0.951, \mathrm{p}<0.01$ and $\mathrm{r}=0.929, \quad \mathrm{p}<0.01) \quad$ respectively. Visfatin also positively correlated with fasting plasma glucose $(\mathrm{r}=0.841$, $\mathrm{p}<0.01)$ in women with PCOS and
BMI $>25 \mathrm{Kg} / \mathrm{m}^{2}$ but not in women with PCOS with $\mathrm{BMI}<25 \mathrm{Kg} / \mathrm{m}^{2}$ $(\mathrm{r}=0.076, \mathrm{p}=0.691) . \quad$ In addition, visfatin also positively correlated with, fasting plasma insulin $(\mathrm{r}=$ $0.882, \mathrm{p}<0.01$ and $\mathrm{r}=0.952, \mathrm{p}<0.01)$ and HOMA ( $\mathrm{r}=0.908, \mathrm{p}<0.01$ and $\mathrm{r}$ $=0.942, \mathrm{p}<0.01)$ in women with PCOS groups (II and IV), respectively. In addition, visfatin positively correlated with free testosterone in women with PCOS groups (II and IV), respectively $(\mathrm{r}=$ $0.969, \mathrm{p}<0.01$ and $\mathrm{r}=0.922, \mathrm{p}<0.01)$.

Table 4: Correlations between visfatin and anthropometric, biochemical and hormonal parameters in the whole study group.

\begin{tabular}{|l|c|c|}
\hline Parameters & $\mathrm{r}$ & $\mathrm{p}$ \\
\hline Age & 0.036 & 0.751 \\
BMI & 0.536 & $<0.01$ \\
FSH & -0.590 & $<0.01$ \\
LH & 0.822 & $<0.01$ \\
LH/FSH & 0.803 & $<0.01$ \\
Free testosterone & 0.954 & $<0.01$ \\
Fasting plasma glucose & 0.391 & $<0.01$ \\
Fasting plasma insulin & 0.816 & $<0.01$ \\
HOMA & 0.816 & $<0.01$ \\
Resistin & 0.784 & $<0.01$ \\
\hline
\end{tabular}

$P<0.05$ was considered significant. 


\section{DISCUSSION}

Polycystic ovary syndrome is a heterogeneous syndrome characterized by hyperandrogenism and insulin resistance ${ }^{(\mathbf{1})}$. The aim of the study is to assess the relationship between both serum resistin and plasma visfatin and insulin resistance and hyperandrogenism in PCOS patients.

In the present study, serum resistin levels in the women with PCOS were significantly higher compared with control women. Previous studies reporting serum resistin concentrations in women with PCOS are inconsistent. Although one small study of Asian subjects observed a 2-fold higher concentration of resistin mRNA expression in adipocytes from subjects with $\operatorname{PCOS}^{(43)}$, there was no difference in the circulating resistin concentration between women with PCOS and controls. In contrast, serum resistin was significantly elevated in other studies $^{(44,45)}$

In the current study, when subjects were segregated according to BMI, women with PCOS and BMI > $25 \mathrm{Kg} / \mathrm{m}^{2}$ had significantly higher resistin concentrations than women with $\mathrm{BMI}<25 \mathrm{Kg} / \mathrm{m}^{2}$ with or without PCOS. On the other hand, in women with PCOS and $\mathrm{BMI}<25 \mathrm{Kg} / \mathrm{m}^{2}$, the resistin levels were similar to control women with $\mathrm{BMI}<25 \mathrm{Kg} / \mathrm{m}^{2}$. These results are in accordance with those of Panidis et al. ${ }^{(44)}$, who reported that serum resistin levels were significantly higher in women with PCOS and BMI $>25 \mathrm{Kg} / \mathrm{m}^{2}$. Also, a significant positive correlation between serum resistin concentration and BMI was observed. DegawaYamauchi et al. ${ }^{(46)}$ reported a positive correlation between resistin and BMI, while Lee et al. found no correlation $^{(30)}$. The current observations support the concept that there may be a relationship between obesity and circulating resistin concentrations.

The altered levels of resistin may be the consequence of altered adipose tissue function and also may be due to a difference in fat distribution in those women with PCOS which have proportionally more visceral adipose tissue $^{(47)}$. Such finding is ascertained by the work of Curat et al. ${ }^{(4)}$, who reported that the increased macrophage population in obese human visceral white adipose tissue (WAT) might be responsible for the enhanced production of chemokines as well as resistin .In fact, it has been suggested that differences in adipose tissue distribution may influence the secretion of the different adipocytokines $^{(\mathbf{4 9})}$

Evidence concerning the role of resistin in the development of insulin resistance remains controversial. Some studies support the proposal of Steppan et al. ${ }^{(15)}$ that resistin is a hormone that links obesity to insulin resistance and diabetes ${ }^{(23,50)}$. Others show quite the opposite ${ }^{(21,24)}$. Inconsistencies between in vivo studies and experiments conducted on isolated adipocytes can be explained by the fact that, in situ, stromovascular elements of adipose tissue, which are more abundant in obese individuals contribute significantly to the production of resistin $^{(21)}$. 
In the present study, resistin levels did not differ significantly between women with BMI $<25 \mathrm{Kg} / \mathrm{m}^{2}$ (groups I and II). However, women with PCOS and BMI $<25 \mathrm{Kg} / \mathrm{m}^{2}$ had higher levels of insulin, higher HOMA index, in other words, they were more resistant to insulin. Nevertheless, resistin levels were significantly higher in women with BMI $>25 \mathrm{~kg} / \mathrm{m}^{2}$ (groups III and IV) compared to women with normal BMI (groups I and II), as were blood glucose and insulin levels and HOMA index.

In addition, in the current present work, resistin correlated positively with BMI, fasting plasma glucose, fasting plasma insulin and HOMA index in women with $\mathrm{BMI}>25 \mathrm{~kg} / \mathrm{m}^{2}$ (groups III and IV). In other words, resistin was found to correlate significantly with all obesityassociated parameters. These findings suggest that resistin is not associated with insulin resistance of PCOS that is not induced by obesity.

In the present study population the free testosterone levels were significantly higher in females with PCOS (groups II and IV) compared to controls (I and III). Pandidis et al. reported decreased levels of sexhormone-binding globulin (SHBG) in PCOS females. Nestler et al. determined that the reduced levels of SHBG were further induced by obesity $^{(\mathbf{9})}$. That relationship explains the higher levels of free testosterone in women with PCOS and BMI $>25$ $\mathrm{kg} / \mathrm{m}^{2}$ compared with women with PCOS and normal BMI.

Also, there was a significant positive correlation between serum resistin and testosterone in PCOS patients (groups II and IV) only. Munir et al. ${ }^{(45)}$ showed similar results. On the contrary, Pandidis and coworkers $^{(44)}$ found no correlation between serum resistin and testosterone. In our study, there was no correlation between circulating resistin and testosterone in control subjects and between BMI and testosterone, indicating that there may be important differences in polycystic ovaries facilitating the responsiveness of the theca cells to resistin. The current results apparently support the notion that, resistin in vitro, can increase ovarian androgen production by directly stimulating ovarian theca cells ${ }^{(45)}$. These data raise the possibility that resistin may play a role in augmenting androgen biosynthesis in women with PCOS.

Our data showed that plasma visfatin levels were higher in women with PCOS (groups II and IV). Similar results were reported by Chan et al. ${ }^{(51)}$, Tan et al. ${ }^{(52)}$ and Kowalska et al. $^{(53)}$ '

The mechanisms controlling cellular visfatin secretion have not yet been characterised. Circulating visfatin concentrations were found to be correlated with the amount of visceral fat in healthy non-obese humans ${ }^{(4)}$. Women with PCOS have an increased prevalence of visceral obesity and metabolic syndrome ${ }^{(1,2)}$.

Recently, it has been shown that visceral adipose tissue produces visfatin, which may regulate insulin sensitivity $^{(31)}$. Higher plasma levels of visfatin in patients with type 2 diabetes mellitus and women with gestational diabetes mellitus have been found ${ }^{(54,34)}$. 
Patients with PCOS often display an impairment of insulin-stimulated glucose utilization in peripheral tissue $^{(55)}$. Furthermore, the ability of norepinephrine to stimulate lipolysis in visceral fat cells has been shown to be $50 \%$ higher in women with $\operatorname{PCOS}^{(56)}$. It has also been suggested that visfatin is released from fat cells during lipolysis ${ }^{(57)}$.

The insulin-mimetic action of visfatin has been proposed to contribute to the development of the metabolic syndrome ${ }^{(31)}$. Women with PCOS (groups II and IV), in the present study, have a higher incidence of insulin resistance. We noted a positive correlation between plasma visfatin levels and both insulin and HOMA, as previously reported by some authors ${ }^{(34)}$ but not others ${ }^{(33)}$.

The correlation observed in our study indicates a possibility that in certain conditions visfatin cannot exert its potential beneficial metabolic actions or its increase is a secondary event in order to prevent further development of insulin resistance.

There is still confusion over the exact relationship between plasma visfatin concentrations and BMI. Berndt et al. demonstrated a significant correlation between the two ${ }^{(33)}$. However, Chen et al. demonstrated no correlation $^{(34)}$. A difference in fat distribution in women with PCOS may result in changed adipose tissue function and adipokine levels ${ }^{(47)}$. Our study tested whether there was any correlation between visfatin levels and BMI and whether there was any difference between women with PCOS and those with a regular menstrual cycle. Interestingly, we found a significant positive correlation between visfatin levels and BMI in subjects with PCOS but not in normal healthy women . The body fat distribution and body shape of subjects with PCOS shift strongly towards the android direction, with significantly increased upper trunk obesity and significantly decreased leg subcutaneous adipose tissue development ${ }^{(58,59)}$. Patients with PCOS show metabolic abnormalities combined with a more android type of adiposity than that found in control group subjects with similar $\mathrm{BMI}^{(\mathbf{6 0})}$. The development of obesity, upper body fat distribution, or both might increase visceral fat cell lipolysis ${ }^{(56)}$. Moreover, there is a unique lipolysis up-regulating alteration in visceral fat cells in subjects with PCOS because of a selective increase in the function of the protein kinase A-hormonesensitive lipase complex. In visceral fat cells, the lipolytic effect is increased $^{(56)}$.

Our data showed that plasma visfatin correlated positively with free testosterone in PCOS women (groups II and IV) but not with controls. That finding was contradictory to that reported by Chan et al. ${ }^{(51)}$ who did not find such correlation. On the other hand Kowalska et al. ${ }^{(53)}$ found such correlation in lean PCOS women only. The explanation of the association between visfatin and androgens is at present unknown.

This may indicate that visfatin could influence ovarian androgen secretion, however, we cannot rule out the influence of other unknown factors, which might regulate the release of both substances. Fukahara et al. $^{(31)}$ reported that visfatin exerts insulin-mimetic properties through 
stimulation of insulin receptor. In view of the fact that hyperinsulinemia might stimulate ovarian androgen synthesis and secretion $^{(5)}$ and thus contribute to the pathogenesis of PCOS, it is possible that relationships observed in our study might be due to insulin-like visfatin action.

The present results showed that in the whole study group, visfatin correlated positively with resistin, while in subgroup analysis, such correlation was found only in women with PCOS (groups II and IV).

As previously mentioned women with PCOS have proportionally more visceral adipose tissue ${ }^{(\mathbf{1})}$ and Curat et al. ${ }^{(48)}$ reported that the increased macrophage population in human visceral white adipose tissue (WAT) might be responsible for the enhanced production of chemokines as well as resistin and visfatin specially in obese subjects.

In conclusion, the results of the study showed that women with PCOS exhibit higher serum resistin and plasma visfatin levels than control subjects. The present data suggest that resistin levels correlate with insulin resistance as a consequence of obesity itself, rather than a, causative factor. We also arise the possibility that resistin may play a role in augmenting androgen biosynthesis in women with PCOS. The positive correlation between plasma visfatin levels and both insulin and HOMA possibly indicates that in certain conditions visfatin cannot exert its potential beneficial metabolic actions or its increase is a secondary event in order to prevent further development of insulin resistance. Finally, the positive correlation of visfatin with free testosterone in PCOS women could be explained by the insulin-like visfatin action that might stimulate ovarian androgen synthesis and secretion and thus contribute to the pathogenesis of PCOS.

\section{REFERENCES}

1. Polson DW, Adams J, Wadsworth $J$ and Franks $S$. (1988): Polycystic ovaries-a common finding in normal women. Lancet 1:870-872.

2. Taylor AE. (1998): Polycystic ovary syndrome. Endocrinol. Metab. Clin. North Am., 27:877902.

3. Apter D, Butzow T, Laughlin GA and Yen SS. (1995): Metabolic features of polycystic ovary syndrome are found in adolescent girls with hyperandrogenism. J. Clin. Endocrinol. Metab., 80:2966 2973.

4. Dunaif A. (1994): Molecular mechanisms of insulin resistance in the polycystic ovary syndrome. Semin. Reprod. Endrocrinol., 12:15-20.

5. Adashi EY, Resnick CE, D'Ercole AJ, Svoboda ME and Van Wyk JJ. (1985): Insulin-like growth factors as intraovarian regulators of granulosa cell growth and function. Endocr. Rev., 6:400-420.

6. Nestler JE, Powers LP, Matt DW, Steingold KA, Plymate SR, Rittmaster RS,Clore JN and Blackard WG.(1991): A direct effect of hyperinsulinemia on serum sex hormonebinding globulin levels in obese women 
with the polycystic ovary syndrome. J. Clin. Endocrinol. Metab., 72:83-89.

7. Ehrmann DA, Barnes RB, Rosenfield RL, Cavaghan MK and Imperial J. (1999): Prevalence of impaired glucose tolerance and diabetes in women with polycystic ovary syndrome. Diabetes Care 22:141-146.

8. Futterweit W. (1999): Polycystic ovary syndrome: clinical perspectives and management. Obstet .Gynaecol .Surv .,54:403413

9. Carmina E. (2003): Genetic and environmental aspects of polycystic ovary syndrome. J. Endocrinol. Invest., 26 11511159.

10. Fasshauer $M$ and Paschke $R$. (2003): Regulation of adipocytokines and insulin resistance. Diabetologia 461594 1603.

11. Arner P. (2005): Insulin resistance in type 2 diabetes-role of adipokines. Curr. Mol. Med., 5:333-339.

12. Zhang $Y$, Proenca R, Maffei $M$, Barone $M$, Leopold $L$ and Friedman JM (1994): Positional cloning of the mouse obese gene and its human homologue. Nature 372:425-432.

13. Hotamisligil GS, Armer P, Caro JF, Atkinson RL and Spiegelman BM (1995): Increased adipose tissue expression of tumor necrosis factor-alpha in human obesity and insulin resistance. J. Clin. Invest., 95:2409-2415.

14. Fernandez-Real JM, Vayreda M, Richart C, Gutierrez C,
Broch M, Vendrell $\mathbf{J}$ and Ricart W.(2001): Circulating interleukin 6 levels, blood pressure, and insulin sensitivity in apparently healthy men and women. J. Clin. Endocrinol. Metab., 83:11541159.

15. Steppan CM, Balley ST, Bhaf S, Brown EJ, Banerjee RR, Wright CM, Patel HR, Ahima RS and Lazar M. (2001) : The hormone resistin links obesity to diabetes. Nature 409:307-312.

16. Stefan $N$, Vozarowa $B$, Funahashi T, Matsuzawa Y, Weyer C, Lindsay RC, Youngren JF, Havel PJ, Pratley RE, Bogardus $C$ and Tataranni PA. (2002): Plasma adiponectin concentration is associated with skeletal muscle insulin receptor tyrosine phosphorylation, and low plasma concentration precedes a decrease in whole-body insulin sensitivity in humans. Diabetes 51:1884-1888.

17. Wood IS, Wang B, Jenkins JR and Trayhurn P. (2005): The pro-inflammatory cytokine IL-18 is expressed in human adipose tissue and strongly upregulated by TNF alpha in human adipocytes. Biochem. Biophys .Res .Commun .,337:422-429.

18. Holcomb IN, Kabakoff RC, Chan B, Baker TW, Gurney A, Henzel W, Nelson C, Lowman HB, Wright BD, Skelton NJ, Frantz GD, Tumas DB, Peale FV Jr, Shelton DL and Hébert CC (2000): FIZZ1, a novel cystein-rich secreted protein associated with pulmonary inflammation defines a new gene family. EMBO J., 19: 4046-4055. 
19. Kim KH, Lee K, Soo Y, Moon YS and Sul HS. (2001): A cysteine-rich adipocyte tissuespecific secretory factor inhibits adipocyte differentiation. J. Biol. Chem ., 276:1152-1156.

20. Steppan CM, Brown EJ, Wright CM, Bhat S, Banerjee RR, Dai CY, Enders GH, Silberg DG, Wen X, Wu GD and Lazar MA. (2001): A family of tissue-specific resistin-like molecules. Proc. Natl .Acad. Sci .USA .,98:502-506

21. Savage DB, Sewter CP, Klenk ES, Segal DG, Vidal-Puig A, Considine RV and O'Rahilly S. (2001): Resistin/Fizz3 expression in relation to obesity and peroxisome proliferator-activated receptor- $\gamma$ action in humans. Diabetes 50:2199-2202

22. Nagaev I and Smith U. (2001): Insulin resistance and type 2 diabetes are not related to resistin expression in human fat cells or skeletal muscle. Biochem. Biophys. Res. Commun., 285: 561-564.

23. McTernan CL, McTernan PG, Harte AL, Levick PL, Barnett AH and Kumar S (2002): Resistin, central obesity, and type 2 diabetes. Lancet 359:46-47.

24. Janke J, Engeli S, Gorzelniak K, Luft FC and Sharma AM. (2002): Resistin gene expression in human adipocytes is not related to insulin resistance. Obes. Res ., 10:1-5

25. Patel L, Buckels AC, Kinghorn IJ, Murdock PR, Holbrook JD, Plumpton C, Macphee $\mathrm{CH}$ and Smith SA. (2003): Resistin is expressed in human macrophages and directly regulated by PPAR $\gamma$ activators. Biochem. Biophys. Res. Commun., 300:472-476.

26. Osawa $H$, Yamada $K$, Onuma H, Murakami A, Ochi M, Kawata $H$, Nishimiya $T$, Niiya T, Shimizu I, Nishida $W$, Hashiramoto M, Kanatsuka A, Fujii Y, Ohashi $J$ and Makino H. (2004): The $G / G$ genotype of a resistin single-nucleotide polymorphism at -420 increases type 2 diabetes mellitus susceptibility by inducing promoter activity through specific binding of Sp1/3. Am. J. Hum .Genet ., 75:678-686

27. Fujinami A, Obayashi $H$, Ohta $K$, Ichimura $T$, Nishimura $M$, Matsui $H$, Kawahara $Y$, Yamazaki M, Ogata M, Hasegawa G, Nakamura N, Yoshikawa T, Nakano $K$ and Ohta M. (2004): Enzyme-linked immunosorbent assay for circulating human resistin: resistin concentrations in normal subjects and patients with type 2 diabetes. Clin. Chim. Acta., 339:57-63

28. Silha JV, Krsek M, Skrha JV, Sucharda P, Nyomba BL and Murphy LJ (2003): Plasma resistin, adiponectin and leptin levels in lean and obese subjects: correlations with insulin resistance. Eur. J. Endocrinol., 149: 331-335.

29. Heilbronn LK, Rood J, Janderova L, Albu JB, Kelley DE, Ravussin E and Smith SR. (2004): Relationship between serum resistin concentrations and insulin resistance in nonobese, obese, and obese diabetic 
subjects. J. Clin. Endocrinol.

Metab., 89:1844-1848.

30. Lee JH, Chan JL, Yiannakouris N, Kontogianni M, Estrada E, Seip R, Orlova $C$ and Mantzoros CS (2003): Circulating resistin levels are not associated with obesity or insulin resistance in humans and are not regulated by fasting or leptin administration: cross-sectional and interventional studies in normal, insulin-resistant, and diabetic subjects. J. Clin. Endocrinol. Metab., 88:48484856.

31. Fukuhara A, Matsuda M, Nishizawa $\mathbf{M}$, Segawa $\mathbf{K}$, Tanaka M, Kishimoto K, Matsuki Y, Murakami M, Watanabe E, Takagi T, Akiyoshi M, Ohtsubo T, Kihara S, Yamashita S, Makishima M, Funahashi T, Yamanaka S, Hiramatsu R, Matsuzawa $\mathbf{Y}$ and Shimomura I. (2005): Visfatin: a protein secreted by visceral fat that mimics the effects of insulin. Science 307: 426-430

32. Samal B, Sun Y, Stearns G, Xie C, Suggs $S$ and McNiece $I$. (1994): Cloning and characterization of the cDNA encoding a novel human pre-Bcell colony enhancing factor. Mol. Cell Biol., 14:1431-1437

33. Berndt J, Kloting N, Kralisch S, Kovacs P, Fasshauer M, Schon MR, Stumvoll $M$ and Bluher M. (2005): Plasma visfatin concentrations and fat depotspecificmRNA expression in humans. Diabetes 54:2911-2916
34. Chen MP, Chung FM, Chang DM, Tsai JCR, Huang H-F, Shin SJ and Lee YJ. (2006): Elevated plasma level of visfatin /pre-B cell colony-enhancing factor in patients with type 2 diabetes mellitus. J. Clin. Endocrinol. Metab., 91:295-299.

35. Rotterdam ESHRE/ASRMSponsored PCOS Consensus Workshop Group (2004): Revised 2003 consensus on diagnostic criteria and long-term health risks related to polycystic ovary syndrome. Fertil .Steril., $81: 19-25$.

36. Willett WC, Dietz WH and Colditz GA (1999): Guidelines for healthy weight. $\mathrm{N}$ Engl J Med., 34:427-434.

37. Trinder L. $\quad$ (1969): Determination of blood glucose using an oxidase -peroxidase system with a non-carcinogenic chromagen. Annals. Clin .Biochem., 24-29.

38. Carmina E, Orio F, Palomba $S$, Cascella T, Longo R A, Colao A M, G Lombardi $G$ and $R A$ Lobo R A. (2005): Evidence for altered adipocyte function in polcystic ovary syndrome . Eur. J. Endocrinol., 152 (3) :389-394.

39. Belgorosky A, Chahin S, Chaler E, Maceiras $\mathbf{M}$ and Rivarola MA. (1996): Serum concentrations of follicle stimulating hormone and luteinizing hormone in normal girls and boys during prepuberty and at early pruberty. J. Endocrinol. Invest., 19(2):88-91.

40. Check JH, Nazari A, Kuhn $R$ and Lauer C.(1996): Relationship of early follicular 
phase sera follicle stimulating hormone and luteinizing hormone levels as measured by a radioimmunoassay and an enzyme-linked immunosorbent assay to number of oocytes retrieved. Clin. Exp. Obstet. Gynecol., 23 (2):83-86.

41. Cumming DC and Wall SR (1985): Non-sex hormone binding globulin-bound testosterone as a marker for hyperandrogenism. J. Clin. Endocrinol. Metab., 61:873-876.

42. Matthews DR, Hosker JP, Rudenski AS, Naylor BA, Treacher DF and Turner RC. (1985): Homeostasis model assessment: insulin resistance and cell function from fasting plasma glucose and insulin concentration in man. Diabetologia 28: 412419.

43. Seow KM, Juan CC, Wu LY, Hsu YP, Yang WM, Tsai YL, Hwang JL and Ho LT (2004): Serum and adipocyte resistin in polycystic ovary syndrome with insulin resistance. Hum .Reprod ., 19:48-53.

44. Panidis D, Koliakos G, Kourtis A, Farmakiotis D, Mouslech T and Rousso D. (2004): Serum resistin levels in women with polycystic ovary syndrome. Fertil. Steril., 81:361-366.

45. Munir I, Yen HW, Baruth T, Tarkowski R, Azziz R, Magoffin DA and Jakiamiuk AJ. (2005): Resistin stimulation of 17alpha-hydroxylase activity in ovarian theca cells in vitro: relevance to polycystic ovary syndrome. J. Clin. Endocrinol. Metab., 90(8):4852-4857.
46. Degawa-Yamauchi $M$, Bovenkerk JE, Juliar BE, Watson W, Kerr K, Jones R, Zhu $Q$ and Considine RV. (2003): Serum resistin (FIZZ3) protein is increased in obese humans. J. Clin. Endocrinol. Metab., 88:5452-5455

47. Kubota N, Terauchi Y, Yamauchi T, Kubota T, Moroi M, Matsui J, Eto K, Yamashita T, Kamon J, Satoh H, Yano W, Froguel P, Nagai R, Kimura S, Kadowaki $T$ and Noda $T$. (2002): Disruption of adiponectin causes insulin resistance and neointimal formation. J.Biol. Chem., 277: 25863-25866.

48. Curat CA, Wegner V, Sengenes C,MiranvilleA, Tonus C, Busse $R$ and Bouloumie A. (2006): Macrophages in human visceral adipose tissue: increased accumulation in obesity and a source of resistin and visfatin. Diabetologia 49:744-747.

49. Wajchenberg BL (2000): Subcutaneous and visceral adipose tissue: their relation to the metabolic syndrome. Endocr. Rev., 21: 697-738.

50. Haugen F, Jorgensen A, Drevon CA and Trayhurn P. (2001): Inhibition by insulin of resistin gene expression in 3T3-L1 adipocytes. FEBS Lett., 507:105108.

51. Chan TF, Chen YL, Chen HH, Lee CH, Jong SB and Tsai EM (2007): Increased plasma visfatin concentrations in women with polycystic ovary syndrome. Fertil. Steril., 88(2):401-405.

52. Tan BK, Chen J, Digby JE, Keay SD, Kennedy CR and 
Randeva HS (2006): Increased visfatin mRNA and protein levels in adipose tissue and adipocytes in women with polycystic ovary syndrome (PCOS): parallel increase in plasma visfatin. J. Clin. Endocrinol. Metab., doi: 10.1210/ jc.2006-0828.

53. Kowalska I , Straczkowski M, Nikolajuk A, Adamska A, Karczewska-Kupczewska $\mathbf{M}$, Otziomek E, Wolczynski S and Gorska1 M. (2007): Serum visfatin in relation to insulin resistance and markers of hyperandrogenism in lean and obese women with polycystic ovary syndrome Human Reproduction 22(7) :1824-1829.

54. Krzyzanowska K, Krugluger W, Mittermayer F, Rahman R, Haider $\mathbf{D}$, Shnawa $\mathbf{N}$ and Schernthaner G (2006): Increased visfatin concentrations in women with gestational diabetes mellitus. Clin. Sci. (Lond)., 110:605-609.

55. O’Meara NM, Blackman JD, Ehrmann DA, Barnes RB, Jaspan JB, Rosenfield RL and Polonsky KS (1993): Defects in beta-cell function in functional ovarian hyperandrogenism. J. Clin. Endocrinol. Metab., 76: 1241-1247.

56. Ek I, Arner P, Ryden M, Holm C, Thorne A, Hoffstedt $J$ and Wahrenberg $H$ (2002): A unique defect in the regulation of visceral fat cell lipolysis in the polycystic ovary syndrome as an early link to insulin resistance. Diabetes 51:484-492.

57. Rongvaux A, Shea RJ, Mulks MH, Gigot D, Urbain J, Leo O and Andris F. (2002): Pre-B-cell colony-enhancing factor, whose expression is up-regulated in activated lymphocytes, is a nicotinamide phosphorribosyltransferase, a cytosolic enzyme involved in NAD biosynthesis. Eur .J. Immunol. 32:3225-3234.

58. Tafeit E, Moller R, Rackl S, Giuliani A, Urdl W, Freytag U, Crailsheim K, Sudi $K$ and Horejsi R. (2003): Subcutaneous adipose tissue pattern in lean and obese women with polycystic ovary syndrome. Exp .Biol .Med. (Maywood)., 228:710-716.

59. Horejsi R, Moller R, Rackl S, Giuliani A, Freytag U, Crailsheim K, Sudi $K$ and Tafeit E. (2004): Android subcutaneous adipose tissue topography in lean and obese women suffering from PCOS: comparison with type 2 diabetic women. Am. J. Phys. Anthropol., 124:275- 281.

60. Strowitzki T, Halser $B$ and Demant T. (2002): Body fat distribution, insulin sensitivity, ovarian dysfunction and serum lipoproteins in patients with polycystic ovary syndrome. Gynecol. Endocrinol .,16:45-51. 


\title{
مستوى الريزيستين فى مصل الد م و فيسفاتين البلازما و علاقتهم بمقاومة الانسولين و زيادة هرمون الذ كورة فى السيدات المصابات بمرض تكيس المبايض
}

\author{
حنان حسنى أحمد * - - نبفين كما ل غمرى" \\ اقسا م الكيميا ء الحيوية ا لطبية ** و امرا ض النساء و التو ليد \\ كلية الطب - جا معة القا هرة
}

الهد ف من هذ ا البحث هو د راسـة العلا قـة بين مستوى الربزبستين فى مصل الد م و فيسفاتين

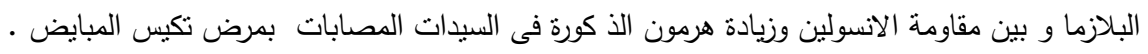

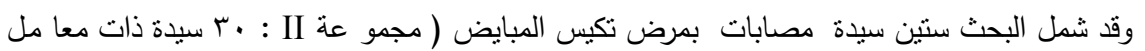

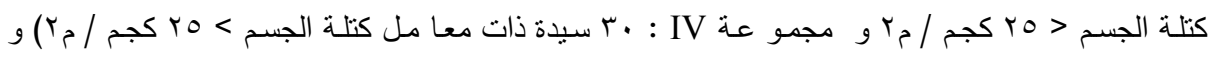

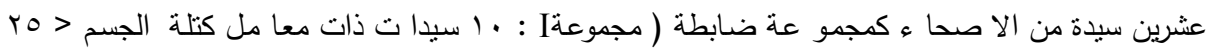

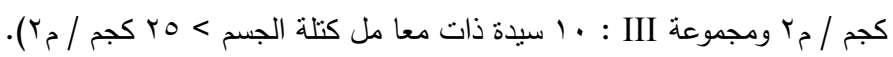

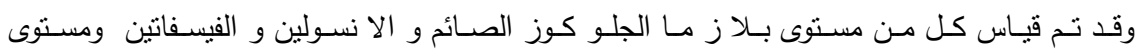

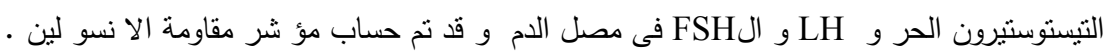

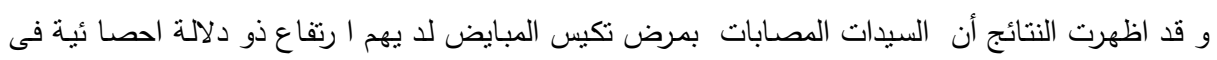

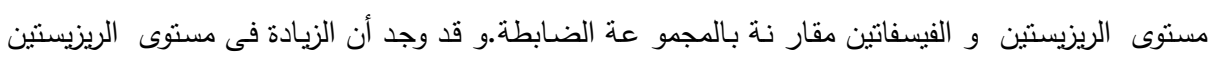

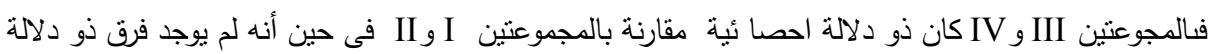

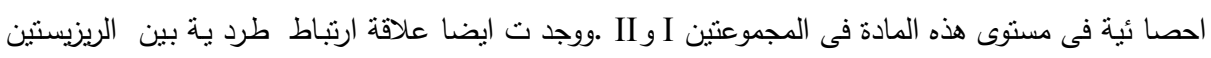

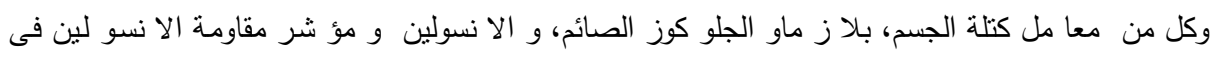

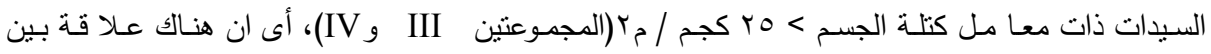
الريزيسنين و كل ما يتعلق بالسمنة .

II أما بالنسبة لفيسفاتين البلازما فقد اوضح البحث وجود ا رتفاع ذو دلالة احصا ئية فى المجموعتين

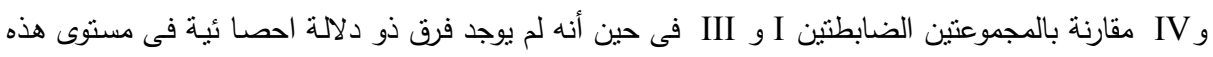

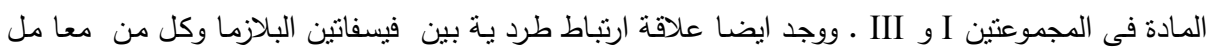

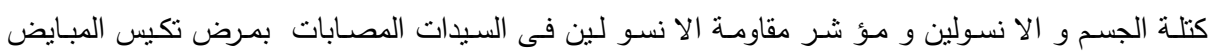

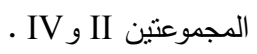




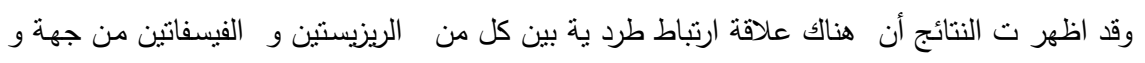

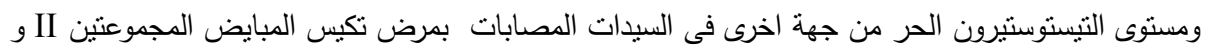

.IV

و قد وجد ت ايضـا علاقة ارتباط طرد يـة بين كل من الريزيستين و الفيسفاتين فى السيدات

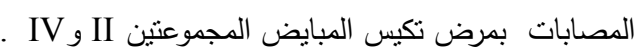

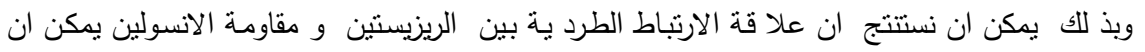

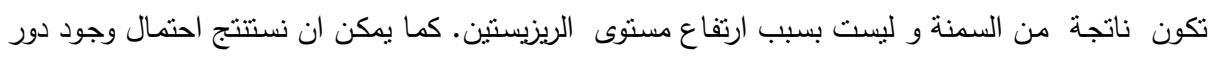

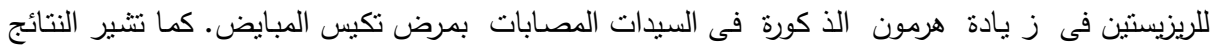

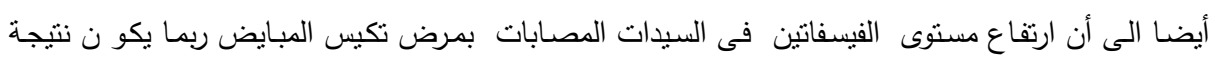

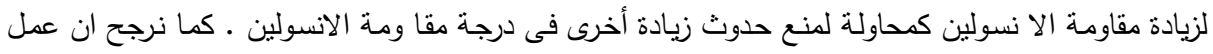

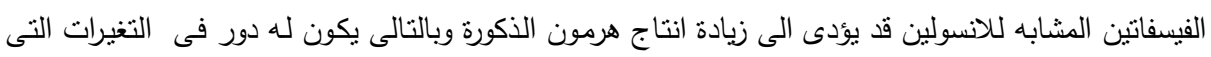

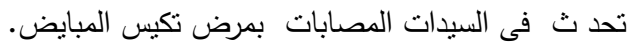

